\title{
Study on Reverse Technology Spillover Effect of OFDI
}

\author{
Li Xiaodi \& Sun Linlin
}

School of Economics and Management, Harbin Engineering University, Harbin, Heilongjiang Province, China.

\begin{abstract}
In order to study whether the foreign direct investment to promote technological progress, this paper calculates the Malm quist TFP according to the methods of Malm quist-DEA and employs Hausman to test the effect to TFP of domestic R\&D capital stock and foreign R\&D capital stockt. Conclusions show that reverse technology spillover effect in Heilongjiang and Liaoning Province do not exist. While Liaoning Province exists.
\end{abstract}

KEYWORD: OFDI; Reverse technology spillover effect; Malmquist index

\section{INTRODUCTION}

Since the generation of endogenous growth theory, international technology spillover theory has become an important topic of research in the fields of economics. OFDI is an important channel of international technology spillover and this point is being confirmed by the research of many scholars. In recent years, the rapid growth of OFDI in developing countries, to some extent, show that the developing countries have motivations that they try to get reverse technology spillover effect from developed host country. This paper based on Malm quist-DEA method and Hausman test for empirical study to the reverse technology spillover effect of foreign direct investment, so as to provide proposals on foreign direct investment.

\section{LITERATURE REVIEW}

Theoretical and empirical research shows that foreign direct investment will generate reverse technology spillover effect. Empirical studies of foreign scholars on the reverse technology spillover effect of OFDI began in 1990s.Ko gut and Chang (1991) for the first time using conclusions of empirical analysis proved that Japanese direct investment in America exists reverse technology spillover effect[1].Head etc.(1999)conduct the research using the data of direct investment of manufacturing enterprises of Japan in American from 1980 to 1992[2]. Lichtenberg, F. and B. van Pottelsberghe de la Potterie(LP,2000) use the data of
American, Japan, Germany and other 13 countries from 1971 to 1990 as samples to test the foreign R\&D spillover effect caused by import, utilization of foreign capital and foreign investment. Head and Ries (2002) start from the perspective of industrial relation characteristics of OFDI and use panel data of 1070 manufacturing firms of Japan to investigate the motivation of different types of OFDI and technology spillover effects on the home country[3]. Nigel Driffield and James H.Love (2003) use the panel data of 1984 to 1992 of British manufacturing sector and use GMM method to test and measure the reverse spillover effects[4]. Branstetter (2006) analyses the technology spillover effect between Japan and America through international capital flow from the enterprise level. Through the econometric analysis confirmed the presence of bidirectional spillover effect.

Yin Jianhua, Zhou Xinyue (2014) on the basis of the consideration of technology gap in reverse spillover effects, establish panel threshold model and use provincial panel data from 2003 to 2010 in China to conduct empirical research[5]. Tian Min, Liu Haiyun, Chen Yijiao (2014) analyze and evaluate reverse technology spillover effect of foreign direct investment of China[6]. Sun huanhuan (2010) uses panel data of 30 provinces of 2003-2007 and LP model to make empirical test on reverse technology spillover effect of China's OFDI. The results find that OFDI has significant positive effect on domestic total factor productivity, but compared with the domestic R\&D stock the influence is relatively weak[7]. Ouyang Yanyan (2010) regards Chinese as the analysis object and generalizes 10 
influence factors of the Chinese reverse technology spillover of foreign direct investment from 3 aspects of innovation capacity of the host country, international technology transfer channels and Chinese digestion and absorption capacity and establish a partial least squares regression model and use computer aided analysis method to conduct empirical test[8]. Bai Jie(2009) based on data of foreign direct investment of 14 major countries and regions of China from 1985 to 2006 and used LP model to estimate the foreign R \& D capital stock overflowed by OFDI and used international R\&D spillover regression method to make an empirical analysis on the effect of reverse technology spillover to total factor productivity[9].

Therefore, this paper tries to inherit and spread from the following two aspects:

(1)On the basis of calculation of total factor productivity in the use of Malm quist-DEA and test the effect of total factor productivity to domestic, foreign capital R\&D overflow by hausman. (2) Deep into specific provinces, we research the reverse technology spillover effect of foreign direct investment in the three northeast provinces.

\section{EMPIRICAL METHODS AND DATA SOURCES}

\subsection{Measurement model}

Coe and Helpman Given the basic measure model of international spillover:

$$
\ln F_{i}=\alpha_{i}^{0}+\alpha_{i}^{d} \ln S_{i}^{d}+\alpha_{i}^{f} \ln S_{i}^{f}
$$

Among them, $F$ indicates TFP, $S^{d}$ in behalf of the domestic R\&D capital stock, $S^{f}$ represents the foreign $R \& D$ capital stock obtained through import trade.

We reference the thinking of L-P(2001) that use the foreign direct investment as the spillover channel and introduced into the model to examine the reverse spillover effect for the first time and establish the following model to conduct empirical analysis:

$$
\ln T F P_{i t}=C+\alpha \ln S_{i t}^{d}+\beta \ln S_{i t}^{f o}+\varepsilon_{i t}
$$

Wherein, $\mathrm{i}$ represents area, $\mathrm{t}$ represents years, $\mathrm{TFP}_{\mathrm{it}}$ indicates the total factor productivity, $\mathrm{Sd}_{\mathrm{it}}$ shows R\&D capital stock around the country, $\mathrm{S}_{\mathrm{it}}^{\mathrm{fo}}$ said foreign $\mathrm{R} \& \mathrm{D}$ spillover obtained by foreign investment, $\alpha$ and $\beta$ respectively represent the domestic and foreign influence on total factor productivity.

Firstly, according to L-P method (2001), we calculate foreign $R \& D$ spillover $\mathrm{S}_{\mathrm{t}}^{\mathrm{fo}}$ in China obtained by foreign investment:

$$
S_{t}^{f o}=\sum \frac{O F D I_{j t}}{Y_{j t}} S_{j t}
$$

Among them, $S_{j t}$ is the $R \& D$ capital stock invested to $\mathrm{j}$ during the period of $\mathrm{t}, \mathrm{OFDI}_{\mathrm{jt}}$ is the investment stock invested to $\mathrm{j}$ during the period of $\mathrm{t}$, $\mathrm{Y}_{\mathrm{jt}}$ is the GDP of $\mathrm{j}$ during the period of $\mathrm{t}$.

In order to measure reverse spillover effect of foreign investment in the provinces, we have added weight of each provinces. Foreign R\&D spillovers $S_{i t}^{\text {fo }}$ obtained by foreign investment in all places can be expressed as:

$$
S_{i t}^{f o}=S_{t}^{f o} \times \frac{O F D I_{i t}}{\sum_{i} O F D I_{i t}}
$$

Among them, OFDI $_{i t}$ is the amount of foreign direct investment in the period of $\mathrm{t}$ in $\mathrm{i}$.

\subsection{The calculation of Malmquist total factor productivity}

This paper uses the malm quist productivity index model based on DEA and the DEAP2.1 software to calculate the total factor productivity (MI), technology progress(TC) and technical efficiency (EC) index of all provinces.

\subsection{Sources of data and data processing}

Data is obtained by calculation of "International Statistical Yearbook", "China Statistical Yearbook", "China Science and Technology Statistics Database", "Chinese Foreign Direct Investment Statistics Bulletin" and the World Bank of corresponding periods.

\subsection{Output and input variables $(K, L)$}

Output variables(Y): output of provinces converted into real GDP with price of 2003 as constant price. GDP and GDP index of 2003-2009 derived from "China statistical yearbook".

Capital stock(K): Provincial capital use the perpetual inventory method to estimate. The basic formula is:

$$
K_{t}=I_{t}+(1-\delta) K_{t-1}
$$

$\mathrm{K}_{\mathrm{t}}$ is the capital stock in the year of $\mathrm{t}, \mathrm{I}_{\mathrm{t}}$ is the gross fixed capital formation in the year of $t$. Original capital stock of the three northeastern provinces of 2003 originate from "estimate of the Chinese provincial capital stock and the typical facts 19782008 Sun Hui"[10]. Gross fixed capital formation over the years originate from China Information Line Database and convert into constant price of 2003 using fixed asset investment price index of provinces. $\delta$ is the capital depreciation rate, the depreciation rate is $5 \%$.

The labor input (L): In this paper, the labor input represented by employment number at the end of the 
year of each province. Data originate from "statistical yearbook" of each province.

\subsection{R\&D capital stock of domestic provinces}

R\&D expenditure data of 2003-2011 of provinces originate from "China Technology Statistical Yearbook". After obtaining each year of R\&D expenditure data, we can follow the sustainable archiving method with 2003 as the base period of the investment and calculated China's domestic capital stock every year for each of the provinces. R\&D stock of the provinces in 2003 from the "Chinese provinces stock index and its research and development _R_D_ computing" _ Xie Lanyun data[11].

\subsection{Foreign R\&D capital stock of Provinces}

In this paper, we select UK, Germany, America, France, Italy, Canada, Australia, Japan, South Korea, Singapore and Taipei of China to represent the overall stock of R\&D of other countries in the world (area) outside china. Data of foreign direct investment stock of China of 2003-2011 originate from the annual "China foreign direct investment statistics bulletin".

\section{EMPIRICAL ANALYSIS}

\subsection{Calculation result of TFP}

We use the panel data of the three northeastern Provinces from 2003 to 2011 and software of DEAP2.1 to calculate the total factor productivity (tfpch), technical progress (techch) and technical efficiency (effch) Change index and the mean. The results are not listed in the article, people who interested can contact me.

\subsection{Hausman test}

Table 1. Hausman test

\begin{tabular}{|l|l|l|l|}
\hline Variable & $\begin{array}{l}\text { Heilongjiang } \\
(\mathrm{RE})\end{array}$ & Jilin(RE) & Liaoning(RE) \\
\hline constant & 0.54051 & -0.56116 & -0.09208 \\
\hline $\ln S F$ & -0.14759 & 0.08601 & -0.00537 \\
\hline $\ln S D$ & 0.35446 & -0.15322 & 0.03519 \\
\hline F Statistic & 171.414 & 33.4829 & 0.542435 \\
\hline$R^{2}$ & 0.94228 & 0.76127 & 0.04912 \\
\hline
\end{tabular}

$*$ RE, FE denote the random effect model and fixed effect model.

The table above shows that the OFDI of Heilongjiang and Liaoning enterprises does not enable R\&D of the host spillover to the motherland, so as to fail to have promoting effect to the growth of total factor productivity. But Jilin does.

\section{CONCLUSION}

\subsection{The main conclusions}

This paper uses the method of Malm quist-DEA and Hausman to test reverse technology spillover effect. Through empirical testing, we get the following conclusions.

(1) OFDI as a way of international technology spillover has different influence on the growth of total factor productivity of the three northeastern provinces. The results show that the reverse technology spillover effect of foreign direct investment in Heilongjiang Province decline continuously and the contribution to technology progress gradually decline during this period. While the reverse technology spillover effect of foreign direct investment in Liaoning Province, Jilin Province gradually increase and the contribution to technology progress gradually upgrade.

(2) Hausman test results show that OFDI of enterprise in Heilongjiang, Liaoning Province do not enable the R\&D spillover to the motherland, so as to fail to promote the growth of total factor productivity. But Jilin Province does.

Based on the above conclusions, we think that reverse technology spillover effect in Heilongjiang and Liaoning Province do not exist, while Liaoning Province exists.

\subsection{Deficiency}

This paper only finds there is no reverse technology spillover effect in Heilongjiang, Liaoning Province through empirical test. We do not make a very thorough analysis on the deep reason that the two provinces do not have reverse technology spillover and the difference between the reasons.

\section{ACKNOWLEDGMENT}

This research was supported by a grant from the HLJ Postdoctoral Science Fund (LBH-Q12137), the Central University Basic Scientific Research Business Expenses Special Funding (HEUCF140909) and the Heilongjiang Province Social Science Foundation (11D090).

\section{REFERENCES}

[1] Kogut,B., Chang,S. Technological Capabilities and Japanese Foreign Direct Investment in the United States. The Review of Economics and Statistics, 1991, (73):401)413.

[2] Head,C. Keith \& Ries, John C. \& Deborah L., Swenson. Attracting foreign manufacturing: Investment promotion and agglomeration. Regional Science and Urban Economics, 1999, 29(2):197 -218. 
[3] Head, C. Keith \& John C., Ries. Offshore production and skill upgrading by Japanese manufacturing firms. Journal of International Economics, 2002, 58(1): 81 -105.

[4] Nigel Driffield and James H. Love. Foreign Direct Investment, Technology Sourcing and Reverse Spillovers. The Manchester School, Vol.71 No.6, 2003, (12).

[5] Yin Jianhua, Zhou Xinyue. Empirical study on reverse technology spillover effect of foreign direct investment in China - based on the technology gap perspective research management, 2014, 03: 131-139.

[6] Tian Min, Liu Haiyun, Chen Yijiao. Evaluation and research on reverse technology spillover effect of foreign direct investment in China SAR economy, 2014, 03: 8991 .
[7] Sun Huanhuan. Chinese OFDI reverses technology spillover effect and its influencing factors. Shandong University, 2010.

[8] OuYang Yanyan. The influence factors of China's foreign direct investment reverse technology overflow analysis. Journal of world economic studies, 2010, 66:66-71 + 89.

[9] Bai Jie. Reverse technology spillover effect of the foreign direct investment - empirical test of the impact of China's total factor productivity. Journal of world economic studies, 2009 preceding: + 89 65-69

[10] Sun Hui, Zhi Dalin, Li Hongjin. Estimate of the provincial capital and typicality fact: 1978 2008. Journal of Guangdong Finance Academy, 2010 01: + 129 103-116.

[11] Xie Lanyun. Chinese province research and development (R\&D) index, and the calculation of stock. Journal of xi'an institute of finance and economics, 2010, 2010:65-71. 